\title{
STUDY ON INVESTOR'S PERCEPTION AND SCHEME PREFERENCE BASED ON COMPARATIVE PERFORMANCE ANALYSIS OF MUTUAL FUND SCHEMES IN COIMBATORE CITY
}

\author{
KAUVYASHREE A $S^{* 1}$, DR. UMA $K^{2} \&$ DR. DEEPA $\mathbf{N}^{3}$ \\ ${ }^{*}$ PG Scholar, Department of Agricultural and Rural Management, Tamil Nadu Agricultural University, Coimbatore, Tamil \\ Nadu, India \\ ${ }^{2}$ Professor, Department of Agricultural and Rural Management, Tamil Nadu Agricultural University, Coimbatore, Tamil Nadu, \\ India \\ ${ }^{3}$ Assistant Professor, Department of Agricultural and Rural Management, Tamil Nadu Agricultural University, Coimbatore,
} Tamil Nadu, India

\begin{abstract}
In India, the stock market offers a wide variety of investment options for investors, to help them invest in different sectors and to focus on ensuring a profitable return. Amongst all financial products, mutual fund ensures maximum returns for investors with its associated risks. Growth and expansion of various mutual fund products in Indian markets has clearly demonstrated as one of the key catalytic instruments for generating significant growth in capital market investment. In this perspective, close monitoring as well as evaluation of these mutual fund schemes have become important. And hence, deciding profitable mutual funds to invest seems to be a challenging task. This research is basically dealt with three major categories of mutual funds offered for the investment by most of the fund houses across India, namely large, mid and small cap funds. The key objective of this paper is to evaluatethe performance of selected mutual fund schemes by means of statistical parameters such as standard deviation, alpha, beta and Sharpe ratio using secondary data. The results obtained from this study will aid investors in their further investment decisions.
\end{abstract}

KEYWORDS: Mutual fund, performance evaluation, statistical parameters

Received: Nov 26, 2020; Accepted: Dec 16, 2020; Published: Jan 05, 2021; Paper Id.: IJASRDEC20205

\section{INTRODUCTION}

Mutual fund is a trust that collects fund from people who share common financial goal. It pools the collected money and invests them in stock market or bonds or debentures or any other financial assets for future returns. Mutual funds are managed by fund manager. Investments are done wide across many secured industries along with various sectors. Thus mutual funds bring about reduced risk. Fund manager fetch some percentage of money from investor for his duty. The commission charge will be around 1-3\% from the investing amount which is termed as 'expense ratio'. Investors in mutual funds are generally referred as unit holders. While an investor is investing his/ her money under any scheme in any Asset Management Company, he/ she being allocated with certain units. The rate of every single unit is called NAV (Net Asset Value). NAV depicts the present market value of single unit.

Over the last decade, mutual funds have progressively become the investor's preferred platform for long- 
fund firms, investors, analysts and policy experts to gain insight into Indian mutual fund's performance.

\section{OBJECTIVE OF THE STUDY}

To compare andanalyse the performance of mutual fund schemes in Coimbatore city.

\section{METHODOLOGY}

The secondary data used for this study were collected from various websites namely AMFIIndia (AUM, Fund categories, Historical NAV), Money Control (Returns) and Value Research (Risk Ratios). Top 5 Asset Management companies are selected based on Average Asset Under Management (AAUM) in which three equity fund categories namely large, mid and small cap funds are selected. Average returns and risk ratios namely Standard Deviation, Jenson's Alpha, Beta and Sharpe Ratio are tools used for the analysis as follows

\section{i.Average Returns of Fund}

Average Returns is used to measure the returns obtained over some period of time in a single number from a series of periodic returns(Prajapati and Patel, 2012).

$$
\text { AverageReturnsof Fund }=\frac{\left(\sum_{i=1}^{i=n} \mathbf{r}_{\mathbf{i}}\right)}{n}
$$

$\mathrm{r}_{\mathrm{i}}=$ Return of the period

$\mathrm{n}=$ Numberof period

\section{ii.Standard Deviation}

Standard Deviation depicts the performance of a fund in respect to the mean(Rani and Hooda, 2017).This will reflect the stability of mutual funds. High standard deviation would not really mean that it is poor since it will typically be higher in the case of equities and lower in the case of stable investments such as debt funds.

$\bar{r}=$ Average Return

$$
\text { StandardDeviation }=\sqrt{\frac{\left(\sum_{i=1}^{i=n}\left(r_{i}-\bar{r}\right)^{2}\right.}{n-1}}
$$

$r_{i}=$ Return of the period

$\mathrm{n}=$ Numberof period

\section{iii.Beta}

Beta evaluates the response of the fund to market fluctuations or volatility. The base value of beta is 1 . If beta value is 1 , the fund reacts similarly to market fluctuations, i.e. the price change is identical to the market movements. By default, Sensex and Nifty's market benchmark index has a beta value of 1.0.Conservative investors could concentrate on low-beta mutual fund schemes (Narayanasamy and Rathnamani, 2013). Aggressive investors can prefer to invest in the mutual fund schemes that have higher beta value with higher returns, bearing more risk.

$$
\beta f=\frac{\sum_{i=1}^{i=n}\left(r_{i}-\bar{r}\right) X\left(m_{i}-\bar{m}\right)}{\sum_{i=1}^{i=n}\left(m_{i}-\bar{m}\right)^{2}}
$$


$\beta_{\mathrm{f}}=$ Beta of the fund

$\mathrm{r}_{\mathrm{i}}=$ Fund Returns for the period $\mathrm{i}$

$\mathrm{m}_{\mathrm{i}}=$ Market Returns for the period $\mathrm{i}$

\section{iv.Jenson's Alpha}

Alpha represents the performance of the asset manager in managing the portfolio to yield profits in accordance to the beta value. The base value for alpha in the Mutual Funds is 0 . In the case of alpha, the value of 0 indicates the performance graph of the fund manager to be exactly in line with the respective benchmark index. Any values in negatives would indicate the performance of the asset manager as underwhelming(Tripathi and Japee, 2020). In addition, alpha in mutual funds above 0 indicates the achievement of fund manager as outperforming compared to the benchmark index. Higher the value of alpha, higher will be the fund's return.

$\alpha_{\mathbf{p}}=\mathbf{R}_{\mathbf{p}}-\left[\mathbf{R}_{\mathbf{f}}+\beta_{\mathbf{p}}\left(\mathbf{R}_{\mathbf{m}}-\mathbf{R}_{\mathbf{f}}\right)\right]$

$\alpha_{p}=$ Alpha of the fund

$\mathrm{R}_{\mathrm{p}}=$ Return of the fund

$\mathrm{R}_{\mathrm{f}}=$ Risk Free Rate of Return (ex. Government bonds, T- bills, etc.)

$\beta_{\mathrm{p}}=$ Beta of the fund

\section{v.Sharpe Ratio}

The Sharpe Ratio (SR) is another essential indicator that shows the return generated by the fund in accordance to the risk taken. According to Roy and Ghosh (2012) ratio is used for the funds which have low correlation with the benchmark index. It allows an investor to understand if it is a good choice to invest in this fund by taking the associated risk. The higher the Sharpe Ratio, the higher the fund's return of investment compared to amount of the risk taken.

$$
S p=\frac{R_{p}-R_{f}}{\sigma_{p}}
$$

$\mathrm{S}_{\mathrm{p}}=$ Sharpe ratio

$\mathrm{R}_{\mathrm{p}}=$ Average Return of the Fund

$\mathrm{R}_{\mathrm{f}}=$ Risk Free Rate of Return

$\sigma_{\mathrm{p}}=$ Standard Deviation of the Fund

Table 1: Average Assets under Management (AAUM) for each quarter of 2020 (Rs in Lakhs)

\begin{tabular}{|c|l|c|c|c|c|}
\hline $\begin{array}{c}\text { S. } \\
\text { No }\end{array}$ & \multicolumn{1}{|c|}{ Mutual fund name } & Jan- Mar & Apr- Jun & Jul- Sep & Average \\
\hline 1 & SBI Mutual Fund & $\begin{array}{c}37353 \\
660.81\end{array}$ & 36436298.36 & 42136373.90 & 38642111.0 \\
\hline 2 & HDFC Mutual Fund & 36978279.64 & 35618341.70 & 37551641.14 & 36716087.5 \\
\hline 3 & ICICI Prudential Mutual Fund & 35074348.87 & 32629118.05 & 36004860.10 & 34569442.3 \\
\hline 4 & Aditya Birla Sun Life Mutual & 24752167.98 & 21459195.96 & 23867383.17 & 23359582.4 \\
\hline 5 & Fund & 20488371.72 & 18006069.87 & 20003043.85 & 19499161.8 \\
\hline
\end{tabular}

(Source- Amfiindia) 


\section{RESULTS}

\section{Returns}

Table 2: Large Cap Funds

\begin{tabular}{|c|c|c|c|c|c|c|c|c|c|c|c|c|c|c|c|c|}
\hline \multirow{3}{*}{ Funt rame } & \multicolumn{3}{|c|}{2016} & \multicolumn{3}{|c|}{2017} & \multicolumn{3}{|c|}{2018} & \multicolumn{3}{|c|}{2019} & \multicolumn{3}{|c|}{1020} & \multirow{3}{*}{$\begin{array}{l}\text { Avaraso } \\
\text { Euturna } \\
\text { (Wis) }\end{array}$} \\
\hline & \multirow{2}{*}{$\mathrm{suv} g \mathrm{R}$} & \multicolumn{2}{|c|}{ Rvara (6) } & \multirow{2}{*}{ suvge } & \multicolumn{2}{|c|}{ Rosara (6) } & \multirow{2}{*}{$\mathrm{s} \Delta \mathrm{v}(\mathrm{B})$} & \multicolumn{2}{|c|}{ Rusara (6) } & \multirow{2}{*}{ sav } & \multicolumn{2}{|c|}{ Rutara (6) } & \multirow{2}{*}{$\mathrm{s} \Delta \mathrm{v}(\mathrm{R})$} & \multicolumn{2}{|c|}{ Rusara (56) } & \\
\hline & & Surd & $\begin{array}{l}\text { Banch } \\
\text { mark }\end{array}$ & & Sund & $\begin{array}{l}\text { Ratck } \\
\text { mark }\end{array}$ & & Sund & $\begin{array}{l}\text { Batch } \\
\text { mark }\end{array}$ & & 5und & $\begin{array}{l}\text { Ratck } \\
\text { mark }\end{array}$ & & Surd & $\begin{array}{l}\text { Batck } \\
\text { mark }\end{array}$ & \\
\hline 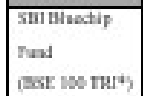 & 3055 & $1 \pi$ & $3 m$ & 19.5s & 31.17 & sn.98 & 35.03 & $-2.9 \mathrm{~s}$ & $1 \mathrm{ss}$ & 44.02 & 12.67 & 225 & 4T.AS & 2.14 & $-4 m$ & 1123 \\
\hline 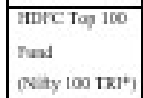 & $302 \pi$ & 5.98 & 344 & 475.36 & 32.92 & $2 x=0$ & 47038 & 1.94 & 1.95 & 52430 & 7.6 & 1004 & 511.56 & -1.54 & 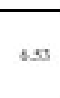 & P.S \\
\hline 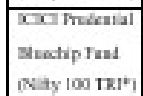 & 31.74 & 5.4 & 34 & 4131 & $13 \times 2$ & zun & $41 s s$ & a.s & 1.95 & 46.71 & woss & 1004 & 4857 & 93 & 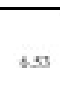 & 11.54 \\
\hline 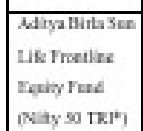 & 179.7 & ses & 2.72 & 22827 & 3204 & 27.95 & 212.6 & -1.35 & $4 m$ & 24505 & sos & 11.93 & $201.4 s$ & 642 & s.t6 & 10.Ts \\
\hline 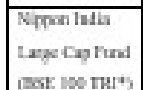 & 24546 & 289 & 2.72 & 34.02 & 39 & 27.95 & 34.57 & 1.35 & $1 \mathrm{ss}$ & וכדנ & 7.52 & 325 & 16.33 & sn & $4 m$ & 875 \\
\hline
\end{tabular}

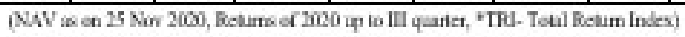

(Souso-Amfincis, Miecyocentol)

(NAV as on 25 Nov 2020, Returns of 2020 up to III quarter, *TRI- Total Return Index)

(Source- Amfiindia, Moneycontrol)

Table 3: Mid Cap Funds

(Benchmark- NIFTY Mid Cap 100 TRI*)

\begin{tabular}{|c|c|c|c|c|c|c|c|c|c|c|c|c|c|c|c|c|}
\hline \multirow{3}{*}{ Fund name } & \multicolumn{3}{|c|}{2016} & \multicolumn{3}{|c|}{1017} & \multicolumn{3}{|c|}{1018} & \multicolumn{3}{|c|}{2019} & \multicolumn{3}{|c|}{2020} & \multirow{3}{*}{$\begin{array}{c}\text { Averaps } \\
\text { Retura } \\
\text { (\%) }\end{array}$} \\
\hline & \multirow{2}{*}{$\begin{array}{c}\text { NAV } \\
\text { El }\end{array}$} & \multicolumn{2}{|c|}{ Return (N) } & \multirow{2}{*}{ SAV (2) } & \multicolumn{2}{|c|}{ Return (K) } & \multirow{2}{*}{$\mathrm{NaV}(2)$} & \multicolumn{2}{|c|}{ Return (N) } & \multirow{2}{*}{$\operatorname{SAV}(2)$} & \multicolumn{2}{|c|}{ Return $(\mathrm{N})$} & \multirow{2}{*}{ XaV (t) } & \multicolumn{2}{|c|}{ Return $(N G)$} & \\
\hline & & Fund & $\begin{array}{l}\text { Beach } \\
\text { mark }\end{array}$ & & Fund & $\begin{array}{l}\text { Beach } \\
\text { mark }\end{array}$ & & Fund & $\begin{array}{l}\text { Beach } \\
\text { mark }\end{array}$ & & Fuad & $\begin{array}{l}\text { Beach } \\
\text { mark }\end{array}$ & & Fund & $\begin{array}{l}\text { Beach } \\
\text { Mark }\end{array}$ & \\
\hline $\begin{array}{l}\text { SHI Magnim } \\
\text { Midoap Fund }\end{array}$ & 68.69 & 5.98 & 6.96 & 85.77 & 35.02 & 45.75 & 73.26 & -17.1 & -15.32 & 75.28 & 0.35 & -4.42 & 85.25 & 21. 87 & 15.00 & 9.224 \\
\hline $\begin{array}{l}\text { HDFC Nial Cip } \\
\text { Opposturitios } \\
\text { Fund }\end{array}$ & 44.19 & 11.66 & 6.96 & 60.12 & 43.06 & 45.75 & 54.10 & -10.17 & -15.32 & 56.31 & 0.62 & -4.42 & 64.50 & 16.45 & 15.00 & 12.332 \\
\hline $\begin{array}{l}\text { ICICI Predential } \\
\text { Midcap Fund }\end{array}$ & 75.98 & 5.04 & 6.96 & 106.41 & 44.48 & 45.75 & 96.9 & -9.76 & -15.32 & 101.24 & 0.26 & -4.42 & 110.33 & 12.79 & 15.00 & 10.562 \\
\hline $\begin{array}{l}\text { Adilya Birla Sun } \\
\text { L.ife Mid Cap } \\
\text { Fund }\end{array}$ & $\begin{array}{c}247.6 \\
3\end{array}$ & 5.82 & 6.96 & 337.47 & 46.25 & 45.75 & 290.71 & -15.01 & -15.32 & 288.53 & -3.16 & -4.42 & 300.91 & 9.44 & 15.00 & 8.668 \\
\hline $\begin{array}{l}\text { Nippese India } \\
\text { Gruwth Fund } \\
\text { (BSE Mal } \\
\text { Cap TRI") }\end{array}$ & $\begin{array}{c}863.6 \\
8\end{array}$ & 3.87 & 7.88 & 1201.27 & 45.32 & 47.02 & 1078.75 & -1063 & -13.44 & 1180.47 & 6.81 & -297 & 1.351 .97 & 15.83 & -0.27 & 12.24 \\
\hline
\end{tabular}

(NAV as on 25 Nov 2020, Returns of 2020 up to III quarter, *TRI- Total Return Index)

(Source- Amfiindia, Moneycontrol) 
Table 4: Small Cap Funds

(Benchmark- NIFTY Small Cap 100 TRI*)

\begin{tabular}{|c|c|c|c|c|c|c|c|c|c|c|c|c|c|c|c|c|}
\hline \multirow{3}{*}{ Fund name } & \multicolumn{3}{|c|}{2016} & \multicolumn{3}{|c|}{1017} & \multicolumn{3}{|c|}{2018} & \multicolumn{3}{|c|}{2019} & \multicolumn{3}{|c|}{2010} & \multirow{3}{*}{$\begin{array}{c}\text { Average } \\
\text { Retura } \\
\text { (\%) }\end{array}$} \\
\hline & \multirow{2}{*}{$\mathrm{NaV}(t)$} & \multicolumn{2}{|c|}{ Return $(\mathrm{N})$} & \multirow{2}{*}{$\operatorname{sav}(z)$} & \multicolumn{2}{|c|}{ Return (\$) } & \multirow{2}{*}{ SAV (D) } & \multicolumn{2}{|c|}{ Retura (N) } & \multirow{2}{*}{$\operatorname{Sav}(0)$} & \multicolumn{2}{|c|}{ Return (N) } & \multirow{2}{*}{$\operatorname{NaV}(2)$} & \multicolumn{2}{|c|}{ Retura (N) } & \\
\hline & & Fund & $\begin{array}{l}\text { Beach } \\
\text { mark }\end{array}$ & & Fuad & $\begin{array}{l}\text { Beach } \\
\text { mark }\end{array}$ & & Fund & $\begin{array}{l}\text { Beach } \\
\text { mark }\end{array}$ & & Fund & $\begin{array}{l}\text { Beach } \\
\text { mark }\end{array}$ & & Fund & $\begin{array}{l}\text { Beach } \\
\text { mark }\end{array}$ & \\
\hline 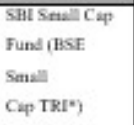 & 37.30 & 0.39 & $2.0 \%$ & 61.08 & 78.66 & 58.16 & 52.36 & -19.66 & -23.72 & 58.23 & 6.06 & -7.23 & 71.28 & 24.97 & 7.22 & 18.084 \\
\hline $\begin{array}{l}\text { HDFC Stall } \\
\text { Cap, Furd }\end{array}$ & 30.11 & 6.06 & 2.94 & 45.51 & 62.65 & 55.97 & 4.37 & -7 & -25.74 & 41.51 & -905 & -9.91 & 45.34 & 10.84 & 11.86 & 12.7 \\
\hline $\begin{array}{l}\text { ICICI Pradenlial } \\
\text { Senall Cap Fund }\end{array}$ & 21.63 & 6.58 & 2.94 & 30.15 & 43.34 & $\$ 5.97$ & 23.71 & -21.81 & -29.74 & 26.34 & 10.62 & -9.91 & 30.43 & 14.92 & 11.86 & 10.73 \\
\hline $\begin{array}{l}\text { Adalya Bitla Sun } \\
\text { Life Senall Cap } \\
\text { Fund }\end{array}$ & 29.86 & 9.68 & 2.94 & 44.82 & $58.5 !$ & 55.97 & 35.24 & -21.79 & -29.74 & $32.5 \%$ & -11.03 & -9.91 & 36.15 & 13.46 & 11.56 & 9.766 \\
\hline $\begin{array}{l}\text { Nippen India } \\
\text { Small Cap Fund }\end{array}$ & 29.88 & 5.77 & 2.94 & 45.93 & 64.94 & 55.97 & 41.64 & -15.73 & -29.74 & 40.93 & -1.97 & -9.91 & 48.82 & 20.67 & 11.86 & 14.736 \\
\hline
\end{tabular}

(NAV as on 25 Nov 2020, Returns of 2020 up to III quarter, *TRI- Total Return Index)

(Source- Amfiindia, Moneycontrol)

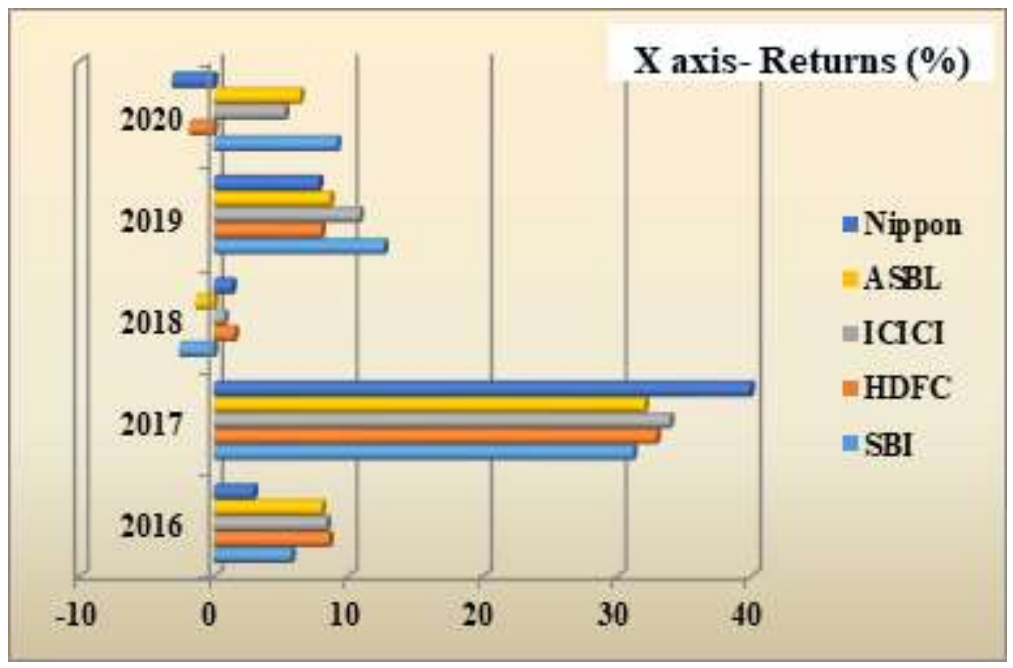

Figure 1: Large Cap Funds 


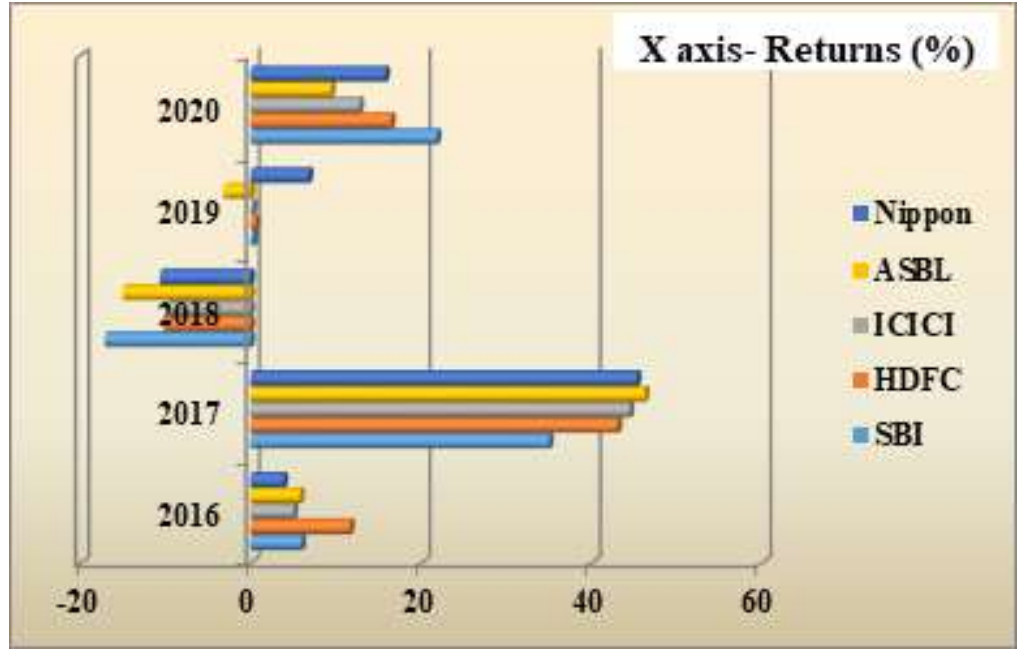

Figure 2. Mid Cap Funds

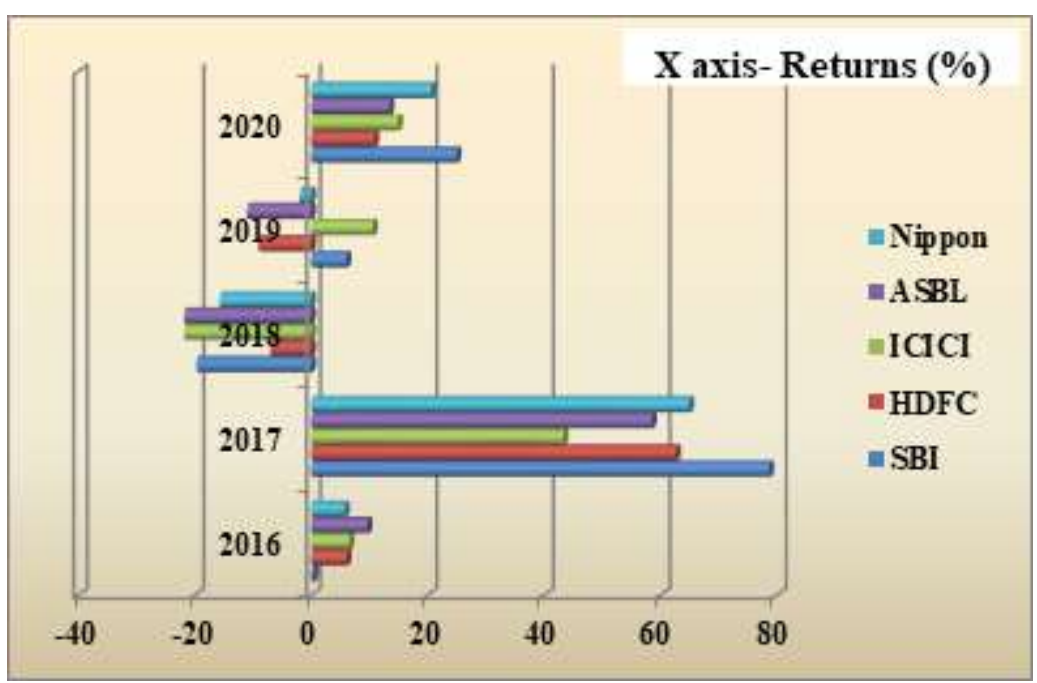

Figure 3. Small Cap Funds

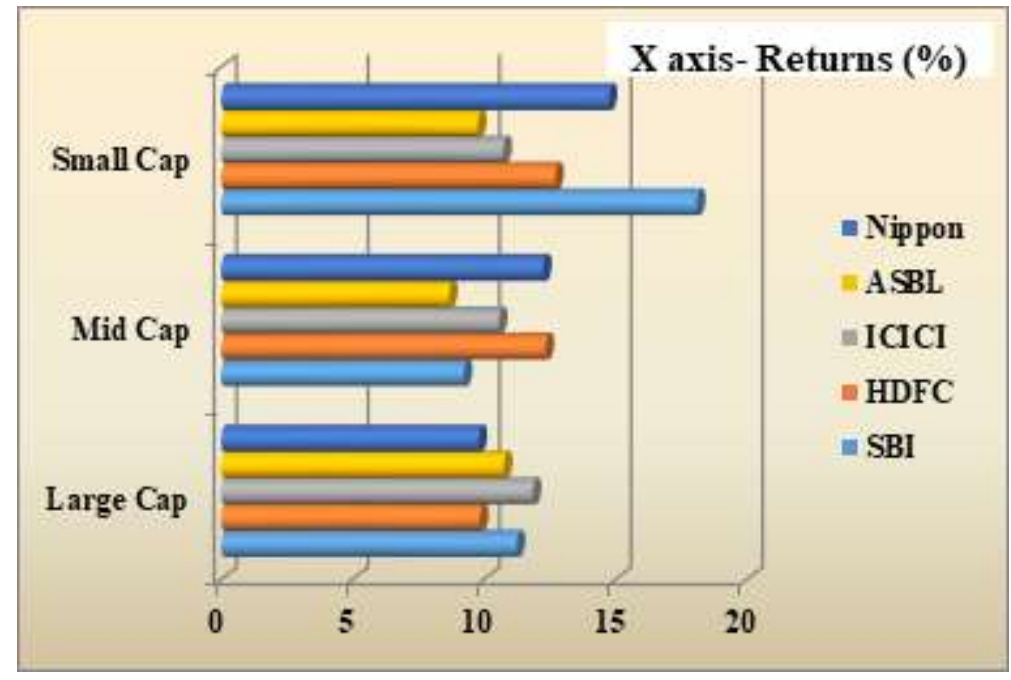

Figure 4: Average 
Table 5.Risk Ratios

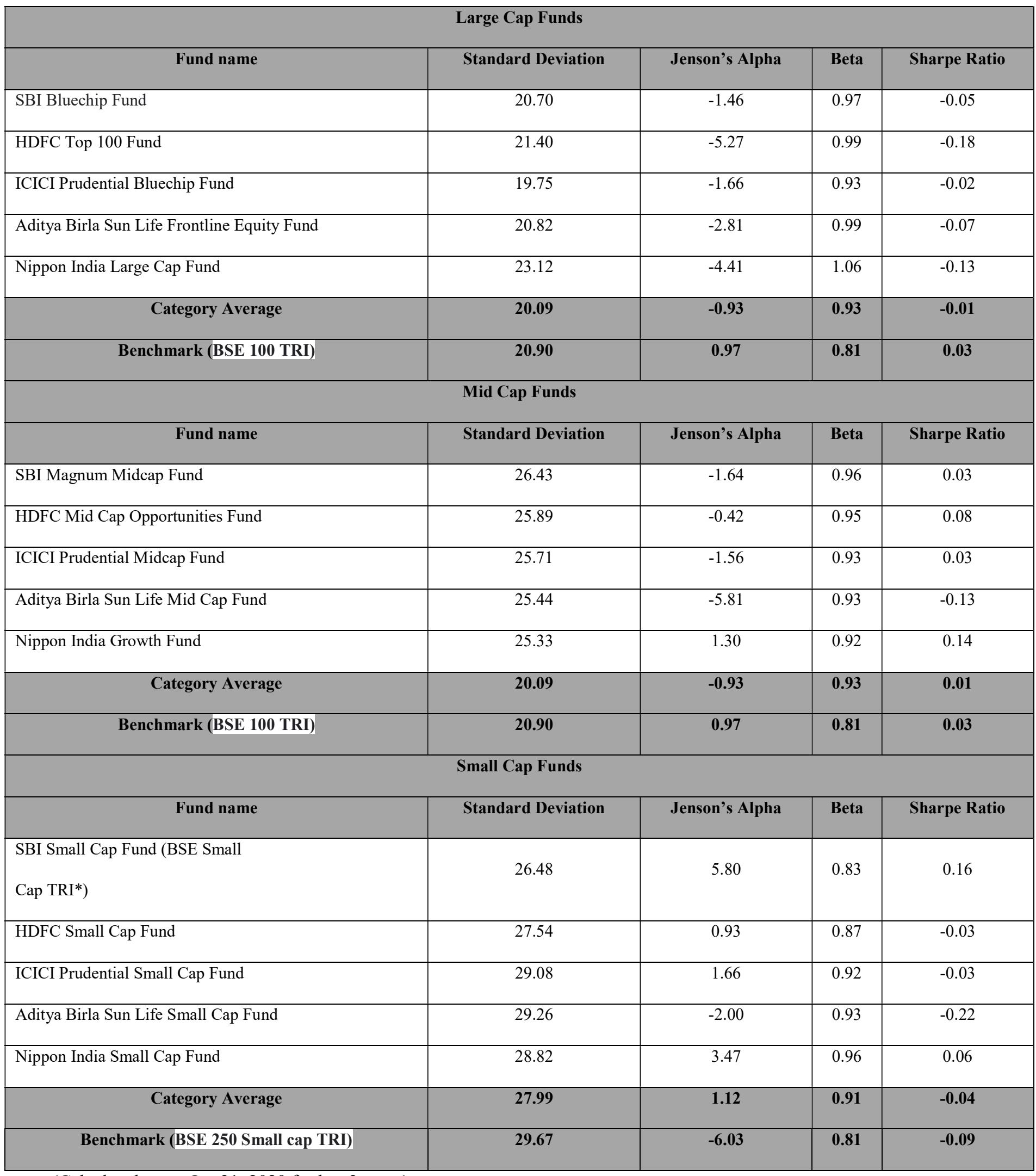

(Calculated as on Oct 31, 2020 for last 3 years)

(Source- Value research)

\section{INTERPRETATION}




\section{I.Returns of Funds}

\section{i) Large Cap Funds}

\section{NAV}

ICICI Prudential Bluechip Fund'sNAV increased from Rs. 31.74 to Rs. 49.57 which shows highest growth percentage of 56.17\%. For HDFC Top 100 fund NAV increased from Rs. 362.73 to Rs. 511.98 which shows lowest growth percentage of $41.14 \%$. On a whole, NAV of large cap funds has increased around $40-50 \%$ in the span of 5 years.

\section{Returns}

In 2016 and 2018, HDFC Top 100 Fund performed the best with the returns of 8.59\% and 1.54\%. In 2019 and 2020, SBI Bluechip Fund performed the best with the returns of $12.67 \%$ and $9.14 \%$ and least percentage of returns with $31.17 \%$ and $-2.58 \%$ during 2017 and 2018 respectively. In 2017, Nippon India Large Cap Fund performed the best with the returns of $39.91 \%$ and lowest returns percentage of 2.95\%, 7.82\% and $-3.11 \%$ during 2016, 2019 and 2020 respectively. In an average ICICI Prudential Bluechip Fund performed the best with the returns of $11.84 \%$ and Nippon India Large Cap Fund being the least performance with $9.78 \%$ returns. Among these selected large cap funds, ICICI Prudential Bluechip Fund has stable performance in the span of 5 years.

\section{ii) Mid Cap Funds}

\section{NAV}

For Nippon India Growth FundNAV increased from Rs. 863.68to Rs. 1351.97which shows highest growth percentage of 56.53\%. For Aditya Birla Sun Life Mid Cap Fund NAV increased from Rs. 247.63 to Rs. 309.91 which shows lowest growth percentage of $25.15 \%$. On a whole, NAV of mid cap funds has increased around $25-57 \%$ in the span of 5 years.

\section{Returns}

In 2016, HDFC Mid Cap Opportunities Fund performed the best with the returns of 11.66\%. In 2017, Aditya Birla Sun Life Mid Cap Fund performed the best with the returns of $46.25 \%$ and lowest returns percentage of $-3.61 \%$ and $9.44 \%$ during 2019 and 2020 respectively. In 2018, ICICI Prudential Midcap Fund performed better compared to other funds with the returns of $-9.76 \%$. In 2019, Nippon India Growth Fund performed the best with the returns of $6.81 \%$ and least percentage of returns with 3.87\% during 2016. In 2020, SBI Magnum Midcap Fund performed the best with the returns of $21.87 \%$ and lowest returns percentage of 35.02\% and $-17.1 \%$ during 2017 and 2018 respectively. In an average HDFC Mid Cap Opportunities Fundperformed the best with the returns of $12.33 \%$ and Aditya Birla Sun Life Mid Cap Fund being the least performance with $8.66 \%$ returns. Among these selected mid cap funds, HDFC Mid Cap Opportunities Fund has stable performance in the span of 5 years.

iii)

Small Cap Funds

\section{NAV}

For Aditya Birla Sun Life Small Cap FundNAV increased from Rs. 29.86to Rs. 36.15which shows highest growth percentage of $21.06 \%$. SBI Small Cap Fund NAV has increased from Rs. 37.30 to Rs. 71.28 which shows lowest growth percentage is $91.09 \%$. On a whole, NAV of small cap funds has increased around $25-57 \%$ in the span of 5 years.

\section{Returns}


In 2016, Aditya Birla Sun Life Small Cap Fundperformed the best with the returns of 9.68\% and lowest returns percentage of -11.03\% during 2019. In 2017 and 2020, SBI Small Cap Fund performed the best with the returns of 78.66\% and $24.97 \%$ along with least percentage of returns with 0.39\% during 2016. In 2018, HDFC Small Cap Fund performed better compared to other funds with the returns of $-7 \%$ and comparatively underperformed than funds during 2020 with $10.84 \%$ returns. In 2019, ICICI Prudential Small Cap Fundperformed better with the returns of 10.62\% and with least performance of $43.34 \%$ and $-21.81 \%$ returns during 2017 and 2018 respectively. In an average SBI Small Cap Fundperformed the best with the returns of $18.08 \%$ and Aditya Birla Sun Life Small Cap Fund being the least performance with 9.76\% returns. Among these selected small cap funds, SBI Small Cap Fundhas stable performance in the span of 5 years.

\section{II.Risk Ratios}

\section{i) Large Cap Funds}

Nippon India Large Cap Fund has higher beta value than other large cap funds. But when average returns, alpha and beta are taken into account together,SBI Bluechip Fund produces higher average returns (11.23\%) with better alpha (-1.46) and beta (0.97) values. ICICI Prudential Bluechip Fund has comparatively higher average returns of $11.84 \%$ with lower standard deviation (19.75) and higher Sharpe ratio (-0.02) which depicts that among the selected large cap funds, this particular fund is less volatile to market fluctuations and takes lesser risk compared to other large cap funds. Therefore, SBI Bluechip Fund and ICICI Prudential Bluechip Fund have performed well with lower risk in this category.

\section{ii) Mid Cap Funds}

SBI Magnum Midcap Fund has higher beta value than other mid cap funds. But when average returns, alpha and beta are taken into account together, HDFC Mid Cap Opportunities Fund and Nippon India Growth Fundproduces higher average returns $(12.33,12.24)$ with better alpha $(-0.42,1.30)$ and beta $(0.95,0.92)$ values and lower standard deviation $(25.89$, $25.33)$ and higher Sharpe ratio $(0.08,0.14)$ which depicts that among the selected mid cap funds, these particular fund are less volatile to market fluctuations and takes lesser risk compared to other mid cap funds. Therefore, HDFC Mid Cap Opportunities Fund and Nippon India Growth Fundhave performed well in this category.

\section{iii) Small Cap Funds}

When average returns, alpha and beta are taken into account together,SBI Small Cap Fund andNippon India Small Cap Fundproduces higher average returns $(18.08,14.73)$ with better alpha $(5.80,3.47)$ and beta $(0.83,0.96)$ values and lower standard deviation $(26.48,28.82)$ and higher Sharpe ratio $(0.16,0.06)$ which depicts that among the selected small cap funds, these particular fund are comparatively less volatile to market fluctuations and takes lesser risk compared to other small cap funds. Therefore, SBI Small Cap Fundand Nippon India Small Cap Fund have performed well.

\section{CONCLUSIONS}

From the following performance evaluation of the chosen five large, mid and small cap funds, it is apparent that all funds performed good during the study period of 5 years (2016-2020), with 2018 being an exception due to market or technical corrections. It is therefore important for investors to understand statistical parameters in order to make sure the stable fund performance. 


\section{REFERENCES}

1. Narayanasamy, R., \& Rathnamani, V. (2013). Performance evaluation of equity mutual funds (on selected equity large cap funds). International Journal of Business and Management Invention, 2(4), 18-24.

2. Kothari, PRITAM P., and Shivganga C. Mindargi. "A study of investors' attitude towards mutual fund with special reference to investors in Solapur City." Management Research (IJAFMR) 3.2 (2013): 1-12.

3. Prajapati, K. P., \& Patel, M. K. (2012). Comparative study on performance evaluation of mutual fund schemes of Indian companies. Researchers World, 3(3), 47.

4. Rani, G., \& Hooda, D. V. S. (2017). Performance Evaluation of Mutual Fund Schemes: A Study of Selected Topper Schemes. Journal of Business and Management, 19, 1-6.

5. Gill, Rupinder Kaur, and Rubeena Bajwa. "Study on Behavioral Finance, Behavioral Biases, and Investment Decisions." International Journal of Accounting and Financial Management Research (2018): 1-14.

6. Roy, S., \& Ghosh, S. K. (2012). A comparative study of mutual fund performance during recession in India. International Journal of Financial Management, 2(2), 53.

7. Sekar, M., M. SHANMUGASUNDRAM, and M. GANASEN. "A Study on Business Growth of MSMEs' in Thoothukudi Districtbefore and after Registering DIC." International Journal of Business Management \& Research (IJBMR) 3.1: 21-30.

8. Tripathi, s., \&Japee, D. G. P. (2020). Performance evaluation of selected equity mutual funds in India

9. DIMITRIOS, BELIAS. "ORGANIZATIONAL CULTURE AND JOB SATISFACTION, IN BANKING SECTOR-A REVIEW." International Journal of Human Resources Management 3.2 (2014): 1-20.

10. www.amfiidia.com

11. www.moneycontrol.com

12. www.valueresearchonline.com 